\title{
MAKNA FIgURATIF PADA SLOgaN UNJUK RASA RKUHP DI MEDIA ONLINETAHUN 2019
}

Pertama diterima : 7 Juni 2021

Bukti akhir diterima : 30 Juni 2021

\author{
M. Diki Lesmana ${ }^{1 *}$, Syarif Hidayatullah ${ }^{2)}$ \\ 1-2) Universitas Muhammadiyah PROF. DR. HAMKA, Jakarta, Indonesia \\ dikilesmana789@gmail.com
}

\begin{abstract}
Abstrak
Penelitian ini bertujuan untuk menganalisis gaya bahasa figuratif atau mengungkapkan makna gaya bahasa figuratif pada slogan unjuk rasa RKUHP di media online pada tahun 2019. Metode yang digunakan adalah deskriptif kualitatif. Jumlah slogan yang dianalisis adalah 43 slogan unjuk rasa RKUHP pada tahun 2019 yang diambil dari media online. Penelitian ini menggunakan teori keraf yang telah dimodifikasi untuk mendapatkan deskripsi oprasional yang meliputi gaya bahasa ironi, sinisme, sarkasme, satire, dan inuendo. Slogan unjuk rasa yang telah dikumpulkan kemudian dianalisis menggunakan pendekatan teori keraf yang meliputi lima gaya bahasa sindiran untuk mengungkapkan makna yang terkandung dalam slogan unjuk rasa RKUHP di media online tahun 2019. Data yang dikumpulkan kemudian dikaji dengan gaya bahasa sindiran menggunakan cara menghadirkan sebuah pembuktian, pernyataan, alasan, dan simpulan dari semua slogan unjuk rasa yang dianalisis. Hasil penelitian menunjukan bahwa slogan yang dianalisis memiliki beragam gaya bahasa sindiran dengan rincian dari hasil pembahasan yang meliputi: gaya bahasa ironi ditemukan sebanyak 8 temuan, sinisme 11 , gaya bahasa sarkasme 12 , gaya bahasa satire 5 , dan gaya bahasa inuendo 7 temuan. Gaya bahasa sarkasme mendapatkan poin yang paling bannyak dari gaya bahasa lainnya yang dianalisis.
\end{abstract}

Kata kunci: makna figuratif, slogan, gaya bahasa sindiran

\begin{abstract}
The purpose of this study is to analyze the figurative language style or to point the meaning of figurative language style on the RKUHP demonstration slogan in online media in 2019. This study applied qualitative-descriptive method. There are 43 slogans analyzed of RKUHP demonstration in 2019 that was taken from online media. This study applied modified Keraf theory to find out the operasional description, such s irony, cynicism, sarcasm, satire, and innuendo. The researcher would analyze the demonstration slogan collected using the approach of Keraf theory including five satire language styles to find out the meaning of RKUHP demonstration slogan in online media in 2019. The data would be analyzed using 5 satire language styles by presenting the proof, statement, reason, and conclusion of all demonstration slogans analyzed. The result of this study showed that there are various satire language styles with the following details of discussion result. There are 8 irony language styles, 11 cynicisms, 12 sarcasms, 5 satires, and 7 innuendos. Sarcasm language style has the biggest point than the other language styles.
\end{abstract}

Keywords: figurative meaning, slogan, satire language style

\section{PENDAHULUAN}

Pada dasarnya pendidik serta pendidikan, dengan kehidupan manusia tidak dapat dipisahkan. Manusia akan mendapatkan ilmu pengetahuan karena adanya pendidikan baik formal ataupun non formal. Salah satu hal yang paling penting dalam segi pengetahuan adalah pendidikan, Tata letak halaman sehingga dalam upaya peningkatan kualitas sumber daya manusia yang berkompetensi dan cerdas adalah dengan mengembangkan pendidikan tersebut. (Khair, 2018)

Dilema yang dihadapi negeri ini begitu beragam, hukum alam selalu berputar, ada kebahagiaan ada pula kesengsaraan, ada pro juga ada kontra dalam menerima kenyataan, sebagaimana yang dialami oleh negeri ini, negeri Indonesia. Permasalahan tidak akan pernah hilang dalam sebuah negara, baik negara berkembang maupun negara maju pasti memiliki problematika yang beragam dan memiliki cara sendiri untuk menghadapi 
dari berbagai situasi. Pendidikan, perekonomian, sosial dan permasalahan yang seringkali dihadapi oleh negeri ini jika ditelaah dengan pemikiran yang logis dan realistis serta melihat kearah hal-hal yang positif akan memberikan sebuah penguatan dan pembelajaran yang tidak ternilai harganya.

Pokok permasalahan yang dihadapi Indonesia dalam pembangunan ekonomi adalah Gross Domestic Product (GDP) yang semakin meningkat, kesenjangan pendapatan yang berkurang serta penghapusan pada kemiskinan. Dilema yang dihadapi Indonesia dan beberapa negara lainnya perihal tujuan antara mengurangi kesenjangan pendapatan atau mengurangi pertumbuhan ekonomi. (Fithrian et al., 2015 dalam Deininger dan Olinto:2000)

Tidak hanya permasalahan dalam bidang ekonomi yang dihadapi oleh negeri atau bangsa Indonesia. akan tetapi permasalahan dalam internal kepemimpinan Indonesia yang sering kali menimbulkan kontravensi akibat putusan serta wewenang yang tidak sesuai dan tidak sejalan dengan masyarakat itu sendiri. Regulasi-regulasi yang disahkan tanpa diperhitungkan dengan matang dan diperhitungkan dengan sebab-akibat yang akan terjadi jika sebuah regulasi itu disahkan.

Akibat adanya ketidak sesuaian regulasi yang dibuat oleh pemerintah maka diadakannya unjuk rasa oleh mahasiswa, pelajar, serikat pekerja dan jurnalis Indonesia adalah untuk pencabutan revisi UU KPK dan penundaan pengesahan RUU, karena pemerintah Indonesia telah mengesahkan revisi undang-undang komisi pemberantasan korupsi dan mengajukan rancangan kitab undang-undang hukum pidana serta rancangan undangundang lainnya. Inilah yang menjadikan alasan unjuk rasa yang dilakukan oleh masyarakat karena dalam regulasi tersebut ada beberapa keputusan-keputusan yang tidak sesuai.

Unjuk rasa atau demonstrasi yaitu sebuah tindakan yang dilakukan sekumpulan orang atau masyarakat untuk menyampaikan dan menyuarakan hal-hal yang dianggap tidak sesuai dengan kenyataan yang dianggap baik oleh pemegang kekuasaan. Kemudian demonstrasi atau unjuk rasa dilakukan sebagai upaya penolakan, kritik dan pesan-pesan yang timbul dari suara rakyat dan harus didengar atau tersampaikan oleh pejabat. (Simanjuntak, 2015)

Unjuk rasa tidak lengkap rasanya jika tidak ada slogan yang dibawa sebagai alat pembantu dalam proses demonstrasi atau unjuk rasa tersebut. Slogan secara bahasa adalah berasal dari bahasa Gaelik, "sluagh-ghairm" yang memiliki arti "teriakan bertempur". Slogan secara istilah adalah frasa atau motto yang sering kali digunakan sebagai ekspresi ide pemikiran ataupun sebagai tujuan yang mudah diingat. Slogan mempunyai bentuk-bentuk yang bervariasi baik tertulis maupun ucapan. Secara umum slogan memiliki pengertian untuk memberikan ruang penyampaian informasi secara rinci, baik disampaikan dalam bentuk ekspresi sosial yang mempunyai tujuan bersama. Kalimat persuasif yang biasanya digunakan dalam slogan. (Zaenuddin, 2020).

Slogan telah diteliti pada kajian mengenai tindak tutur wacana slogan yang dikaji oleh Imam Suyitno dengan topik "Proposisi Bentuk Kosong dalam Wacana Slogan: Kajian Tindak Tutur Wacana Slogan". Penelitian ini terbitkan oleh HUMANIORA pada tanggal 3 Oktober 2005. Suyitno mengatakan bahwa slogan sudah menjadi fenomena dalam penggunaan bahasa yang mempunyai perbedaan dengan fenomena bahasa lainnya. Hasil kajian yang dilakukan oleh Suyitno yaitu tindak tutur dapat digunakan sebagai salah satu pendekatan dalam mengkaji wacana slogan. Dengan pendekatan tindak tutur, suatu tuturan atau wacana tidak hanya dipahami dari struktur teks formalnya saja, tetapi selalu ditelaah dengan tujuan penutur dan konteks tutur lainnya yang mendukung.

Penelitian yang dilakukan oleh Suyitno berbeda dengan penelitian yang dilakukan oleh penulis. Penelitian ini mengkaji makna figuratif dengan objek kajian slogan unjuk rasa RKUHP pada tahun 2019 yang diambil dari media online. Dari semua kajian tentang slogan dan kajian yang telah diutarakan, belum ada yang mengangkat persoalan tentang slogan unjuk rasa. Inilah Alasan dalam menganalisis slogan sebagai objek kajian, karena kajian ini suatu hal yang baru dan menarik untuk dianalisis. Kemudian analisis slogan ini sangat unik dan bermanfaat khususnya untuk khalayak jika hendak melangsungkan unjuk rasa atau demonstrasi. Mahasiswa, pelajar, buruh dan elemen masyarakat lainnya bisa mempelajari makna demonstrasi dan makna slogan sebagai salah satu alat penunjang yang membantu tersuarakannya pesan, kritik dan lain sebagainya yang hendak disampaikan.

Kemudian penelitian relevan kedua yang diteliti oleh Taufik mawardi, dkk dengan judul "Ungkapan figuratif dalam cerpen manusia karya putu Wijaya" penelitian yang dilakukan oleh taufik dkk, berfokus pada objek cerpen dengan mengungkapkan figuratif yang ada pada cerpen tersebut. Penelitian ini sejalan dengan penelitian yang diteliti yaitu mengungkapkan makna figuratif pada slogan unjuk rasa RKUHP pada tahun 2019. Dari kedua penelitian yang telah disampaikan, keduanya memiliki persamaan dalam analisisnya yaitu dengan pendekatan figuratif namun dengan objek yang berbeda.

Selanjutnya akan dikemukakan penelitian dari jurnal Internasional yang diteliti oleh Shorouq K. Al-Houti dan Sultan M. Aldaihani yang menempuh jenjang Pendidikan di sekolah tinggi Pendidikan dasar, Ardhiya, Kuwait. Jurnal Internasional ini diterbitkan oleh Canadian Center of Science and Education. Dengan judul penelitian "Learners in a Tight Corner: An Investigation of Figuratif Idiomatic Competence and Learnerrelated Factors. Penelitian yang dilakukan oleh Shorouq dan Sultan Aldaihani merupakan penelitian yang mengkaji kompetensi dalam kiasan atau figuratif idiom atau bahasa tempat seseorang tinggal, kemudian 
mengemukakan faktor yang mempunyai hubungan dengan pelajar. Penelitian ini relevan dengan penelitian yang sedang dilakukan, yaitu mengungkap makna figuratif atau makna kiasan, hanyasaja objek kajian yang dilakukan oleh Shorouq berbeda dengan objek kajian yang dilakukan. Penelitian ini mengkaji objek pada slogan unjuk rasa RKUHP pada tahun 2019 yang diambil dari media online. Sedangkan penelitian yang dilakukan oleh Shorouq mengkaji objek figuratif, idiom yang terdapat hubungannya dengan pelajar, jadi objek yang diambilnya adalah pelajar. (Al-Houti \& Aldaihani, 2020).

\section{METODE PENELITIAN}

Metode penelitian merupakan ragam ilmiah agar memperoleh data dengan fungsi dan tujuan dari penelitian tersebut. Terdapat beberapa inti dari penelitian yang harus dipahami yaitu, cara ilmiah, tujuan, data, dan kegunaannya. Cara ilmiah yaitu suatu kegiatan penelitian yang mempunyai dasar terhadap ciri-ciri keilmuan, yaitu empiris, rasional, dan sistematis. Kemudian rasional adalah penelitian yang dilakukan menggunakan caracara yang rasional atau masuk akal, sehingga mudah dipahami oleh nalar manusia. Empiris adalah metode penelitian yang dapat diamati oleh indra manusia, sehingga cara-cara yang digunakan dapat diketahui dan dapat diamati oleh orang lain. Kemudian yang terakhir adalah sistematis yaitu, penelitian yang menggunakan langkahlangkah tertentu yang memiliki sifat masuk akal dan mudah dipahami. (Sugiyono, 2015:2)

Pendekatan yang lebih spesifik dalam sebuah penelitian akademis yaitu metode kualitatif dibandingkan dengan metode kuantitatif. Walaupun proses kedua penelitian tersebut relatif sama, akan tetapi tahapan kegiatan atau prosedur kualitatif masih mengandalkan data seperti teks dan gambar, yang mempunyai tahapan-tahapan unik dalam proses analisis datanya dan mempunyai strategi penelitian yang berbeda-beda. (Creswell, 2017).

Makna penelitian kualitatif menurut Tohirin, (2016:6) merupakan penelitian yang memiliki maksud memahami kejadian perihal apa yang dialami oleh subjek penelitian seperti perilaku, tanggapan, semangat atau motivasi, perilaku, dan lain-lain secara holistic dan menggunakan cara deskripsi dengan bentuk kata-kata kemudian bahasa yang digunakan pada suatu konteks khusus yang dirasa cukup alamiah serta memanfaatkan segala metode alamiah.

Penelitian ini menggunakan penelitian deskriptif, penelitian deskriptif menjelaskan secara sistematik serta akurat faktanya dan penelitian deskriptif menjelaskan karakteristik perihal populasi atau bidang-bidang tertentu. Penelitian deskriptif berupaya untuk menggambarkan kejadian atau situasi-situasi. Penelitian deskriptif mengumpulkan data-data yang bersifat deskriptif dan tidak bermaksud untuk mencari penjelasan, membuat prediksi, menguji hipotesis atau bahkan mempelajari implikasi. (Azwar, 2014:7)

Metode penelitian yang digunakan adalah penelitian deskriptif kualitatif dengan teknik analisis data. Penelitian deskriptif merupakan penelitian non hipotesis, sehingga dalam penelitian tidak perlu merumuskan hipotesis. Bersifat kualitatif, yaitu penelitian digambarkan dengan kata-kata atau kalimat yang dipisahkan sesuai kategori untuk menarik kesimpulan. Jadi, metode deskriptif kualitatif dengan menggunakan teknis analisis data ialah menganalisis makna figuratif dalam slogan unjuk rasa RKUHP di media online tahun 2019 agar makna yang terkandung dalam slogan yang dikumpulkan dan dapat digali makna serta pesan yang tertuang dalam slogan tersebut.

Data yang digunakan pada penelitian ini adalah makna figuratif yang diambil dari slogan unjuk rasa RKUHP di media online tahun 2019. Pada penelitian ini mengungkap makna yang terkandung di dalamnya dan menghimpun hasil pembahasan ironi, sinisme, sarkasme, satire, dan inuendo. Dalam sebuah penelitian terdapat 2 (dua) sumber data yaitu, (1) data primer dan (2) data sekunder. Menurut Fajaryati, (2012) dalam setiawan dan saryono (2010) sebuah data dalam penelitian terbagi menjadi dua jenis data, yaitu: (a) data primer, adalah data yang langsung diperoleh dari responden yang menjadi objek dalam proses penelitian ini. (b) data sekunder adalah data yang didapatkan melalui lembaga atau institusi yang telah menghimpun dan mengumpulkan datadata yang sudah tersedia sebelumnya.

Data sekunder adalah data pendukung data primer. Dari pengertian sumber data yang dijelaskan oleh Fajaryati. Penelitian ini disimpulkan bahwa sumber data yang akan digunakan adalah sumber data primer yaitu, akan menggunakan data slogan langsung dari responden yang terdapat di media online dalam proses penelitian ini. Slogan yang akan diteliti berjumlah 40 yang diambil dari media online. Masing-masing slogan akan dibahas sesuai subfokus yang telah ditentukan agar mendapatkan hasil yang sesuai dengan tujuan penelitian ini.

\section{HASIL PENELITIAN DAN PEMBAHASAN}

Penelitian ini menggunakan kumpulan slogan yang diambil di media online perihal unjuk rasa RKUHP yang terjadi pada tahun 2019 yang dijadikan sebuah objek kajian. Slogan ini di latar belakangi dengan masalah sosial maupun politik yang sering kali terjadi dalam suatu negara akibat ketidak sesuaian putusan atau perundang-undangan yang dibuat oleh pimpinan ataupun pemerintah. Masalah ini seringkali terjadi dalam suatu negara dan menimbulkan aksi unjuk rasa yang dilakukan oleh tataran masyarakat yang menentang atau menolak putusan regulasi tersebut.

Penelitian ini cukup unik karena dalam penelitian mengungkapkan makna-makna yang terkandung pada slogan unjuk rasa RKUHP yang diambil di media online pada tahun 2019. Penelitian ini tidak terlepas dari 
kaitan dalam pembelajaran bahasa dan sastra Indonesia karena objek kajian yang diteliti adalah slogan kemudian diungkapkan dengan gaya bahasa figuratif yang didalami dengan subfokus berupa makna ironi, sinisme, sarkasme, satire, dan inuendo.

Berdasarkan 43 temuan slogan unjuk rasa RKUHP di media online tahun 2019 peneliti membagi sloganslogan tersebut menjadi lima subfokus. Subfokus 1 ditemukan dalam slogan unjuk rasa dengan makna figuratif yang dikaji menggunakan ironi, subfokus 2 ditemukan makna figuratif dalam slogan unjuk rasa yang dikaji menggunakan sinisme, subfokus 3 ditemukan makna figuratif dalam slogan unjuk rasa yang dikaji menggunakan sarkasme, subfokus 4 ditemukan makna figuratif dalam slogan unjuk rasa yang dikaji menggunakan satire, subfokus 5 ditemukan makna figuratif dalam slogan unjuk rasa yang dikaji menggunakan inuendo. Hasil temuan tersebut dirincikan sebagai berikut:

\begin{tabular}{|c|l|c|}
\hline No & \multicolumn{1}{|c|}{ Jenis Makna Figuratif } & Jumlah Temuan \\
\hline 1 & Ironi & 8 \\
\hline 2 & Sinisme & 11 \\
\hline 3 & Sarkasme & 12 \\
\hline 4 & Satire & 5 \\
\hline 5 & Inuendo & 7 \\
\hline \multicolumn{2}{|c|}{ Total } & 43 \\
\hline
\end{tabular}

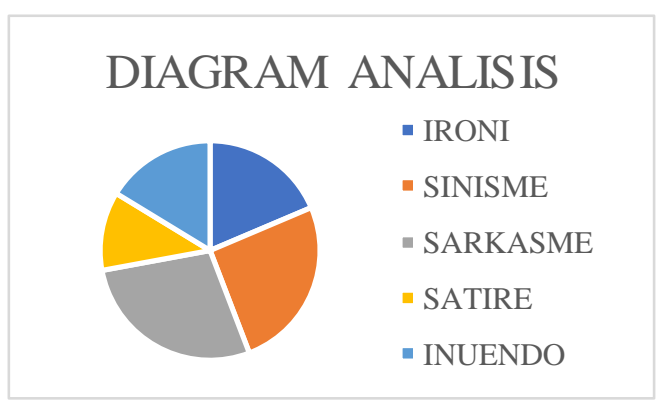

Gambar 1. Data 1 Diagram Hasil Analisis

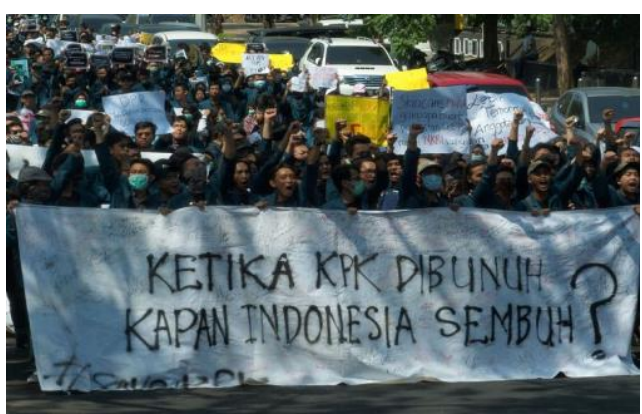

Gambar 2. Data 2 Ironi (tertanggal 18 Mei 2021)

Makna dari kutipan slogan tersebut ialah "Ketika KPK dibunuh kapan Indonesia sembuh, makna yang terkandung dalam slogan ini mengungkapkan bahwa ketika suatu wadah yang membantu menegakan keadilan dalam memberantas korupsi dibunuh maka siapa yang akan mewadahi hal tersebut dan bagaimana Indonesia bisa sembuh dari hal-hal yang berbau korupsi”.

Pembuktian tersebut terdapat pada slogan yang telah diambil dan telah dianalisis, kutipan tersebut memiliki makna ironi atau termasuk kedalam gaya bahasa ironi karena sebagaimana yang telah dijelaskan perihal gaya bahasa ironi yaitu gaya bahasa yang bertentangan atau berbanding terbalik dengan makna sebenarnya, seperti kata "KPK dibunuh" berbanding terbalik dengan kata "Indonesia sembuh". Maka dapat dipastikan kutipan slogan tersebut termasuk kedalam gaya bahasa ironi. Kesimpulannya adalah kutipan slogan tersebut termasuk kedalam jenis gaya bahasa ironi karena mengandung makna bertentangan atau berbanding terbalik dengan makna sebenarnya.

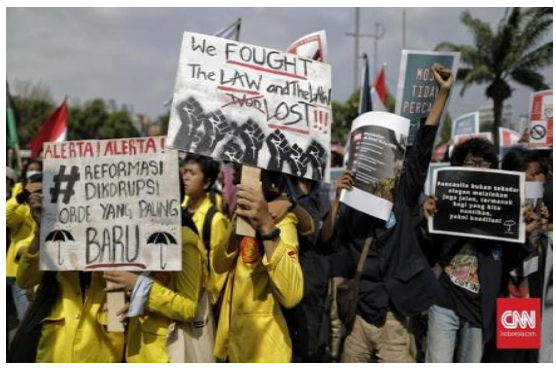


Gambar 3. Data 3 Ironi (tertanggal 18 Mei 2021)

Makna yang terkandung dalam slogan ini adalah masyarakat melawan hukum sudah pasti hukum yang akan menang. Ini adalah salah satu bentuk nyata dalam demokrasi yang ada di Indonesia. Hukum di Indonesia sangatlah lucu, seringkali masyarakat menyuarakan hak-hak nya akantetapi jarang sekali mendapatkan respon yang baik.

Pembuktian tersebut terdapat pada slogan yang telah diambil dan telah dianalisis, kutipan tersebut memiliki makna ironi atau termasuk kedalam gaya bahasa ironi karena sebagaimana yang telah dijelaskan perihal gaya bahasa ironi yaitu gaya bahasa yang bertentangan atau berbanding terbalik dengan makna sebenarnya, hal ini terbukti dalam slogan tersebut pada kata "we fought the law" dan kata "the aw won lost" pada kutipan tersebut tergambarkan dengan jelas memiliki makna ironi. Kesimpulannya adalah kutipan slogan tersebut termasuk kedalam jenis gaya bahasa ironi karena mengandung makna bertentangan atau berbanding terbalik dengan makna sebenarnya, yang seharusnya makna kami melawan menjadi menang, akantetapi yang melawan dia yang kalah.

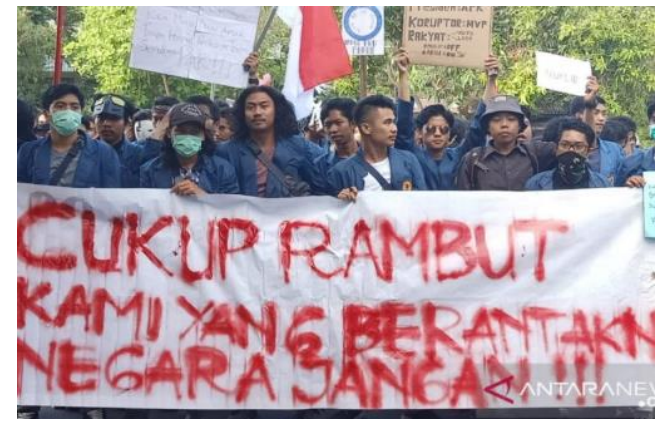

Gambar 4. Data 4 Ironi (tertanggal 18 Mei 2021)

Makna yang terkandung dalam slogan ini adalah cukup rambut kami (Mahasiswa yang mengikuti demonstrasi) jangan sampai negara yang berantakan akibat kebijakan-kebijakan yang diberlakukan oleh DPR. Kata berantakan menunjukan bahwa demonstran yang mengikuti aksi unjuk rasa tidak ingin melihat negara Indonesia ini berantakan sebagaimana rambutnya.

Pembuktian tersebut terdapat pada slogan yang telah diambil dan telah dianalisis, kutipan tersebut memiliki makna ironi atau termasuk kedalam gaya bahasa ironi, sebagaimana yang telah dijelaskan perihal gaya bahasa ironi yaitu gaya bahasa yang bertentangan atau berbanding terbalik dengan makna sebenarnya. Dalam kutipan "rambut kami yang berantakan" dengan "negara jangan" gaya bahasa ironi dalam kutipan slogan ini menunjukan bahwa kutipan tersebut mengandung makna yang terbalik atau bertentangan. Kesimpulannya adalah kutipan slogan tersebut termasuk kedalam jenis gaya bahasa ironi karena mengandung makna bertentangan atau berbanding terbalik dengan makna sebenarnya, hubungan antara rambut dengan negara yang berbanding terbalik dengan makna sebenarnya.

Selaras dengan makna Gaya bahasa ironi merupakan gaya bahasa yang menggunakan sebuah makna dengan sindiran-sindiran sederhana atau kata-kata yang bertentangan dengan keadaan sesungguhnya atau makna yang sebenarnya. Gaya bahasa ironi bermakna sindiran jika pengguna sindiran ataupun yang disindir mengerti apa maksud sindiran yang disampaikan (Mara \& Bahry, 2019)

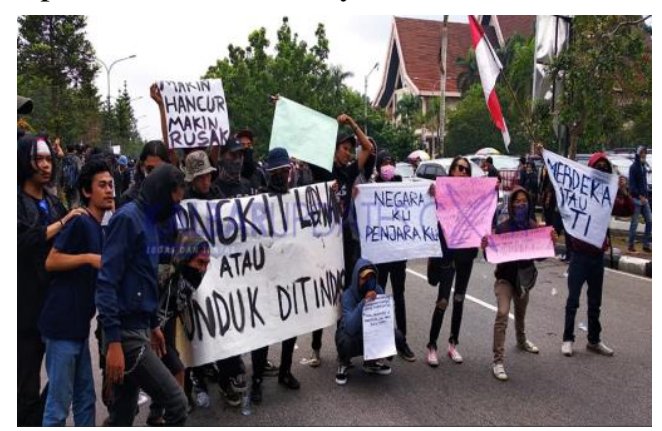

Gambar 5. Data 5 Sinisme (tertanggal 18 Mei 2021) 
Makna yang terkandung dalam kutipan slogan ini adalah "Makin hancur makin rusak" kutipan slogan ini mempunyai makna bahwa semakin hancur negeri ini dan semakin rusak pula negeri ini karena putusan regulasi yang dibuat oleh pemerintahan.

Pembuktian tersebut terdapat pada slogan yang telah diambil dan telah dianalisis, kutipan tersebut memiliki makna sinisme atau termasuk kedalam gaya bahasa sinisme, sebagaimana yang telah dijelaskan perihal gaya bahasa sinisme yaitu gaya bahasa yang dalam ungkapannya tidak memberikan kata pertentangan, sederhananya gaya bahasa sinisme mengejek secara langsung dan berbanding terbalik dengan gaya bahasa ironi. Terbukti pada kata "makin hancur" dan "makin rusak" kata tersebut menunjukan ejekan atau hinaan terhadap kebijakan DPR terhadap regulasi RKUHP yang telah dibuat dan telah disahkan. Kesimpulannya adalah kutipan slogan tersebut termasuk kedalam jenis gaya bahasa sinisme karena mengandung makna yang meledek atau mengejek secara langsung sebagaimana dalam pembahasan yang telah dipaparkan.

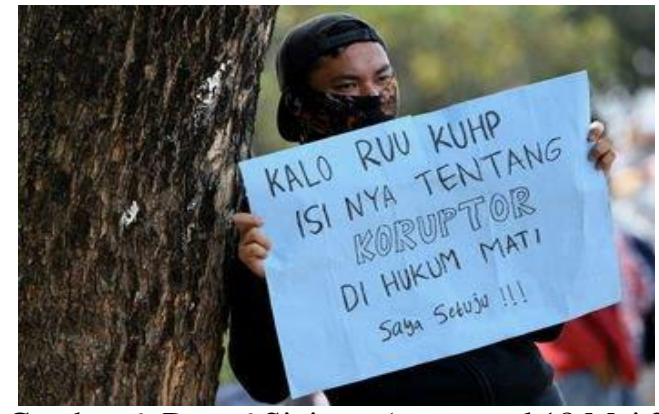

Gambar 6. Data 6 Sinisme (tertanggal 18 Mei 2021)

Makna yang terkandung dalam slogan "Kalo RUU KUHP isinya tentang koruptor dihukum mati, saya setuju" kalimat yang terdapat pada slogan ini mempunyai makna bahwa jika kebijakan untuk menghukum koruptor yang dimuat dalam RKUHP dengan hukuman mati saya akan setuju. Itu menandakan bahwa betapa merugikannya seorang koruptor bagi negara ini.

Pembuktian tersebut terdapat pada slogan yang telah diambil dan telah dianalisis, kutipan tersebut memiliki makna sinisme atau termasuk kedalam gaya bahasa sinisme, sebagaimana yang telah dijelaskan perihal gaya bahasa sinisme yaitu gaya bahasa yang dalam ungkapannya tidak memberikan kata pertentangan, sederhananya gaya bahasa sinisme mengejek secara langsung dan berbanding terbalik dengan gaya bahasa ironi. Hal ini terbukti pada kata "koruptor" dan "dihukum mati" kata-kata tersebut sangatlah menyindir dan mengejek maka kutipan slogan ini sesuai dengan makna gaya bahasa sinisme. Kesimpulannya adalah kutipan slogan tersebut termasuk kedalam jenis gaya bahasa sinisme karena mengandung makna yang meledek atau mengejek secara langsung sebagaimana yang dijelaskan dalam makna gaya bahasa sinisme, terbukti dalam slogan tersebut dengan kata koruptor dan hukum mati.

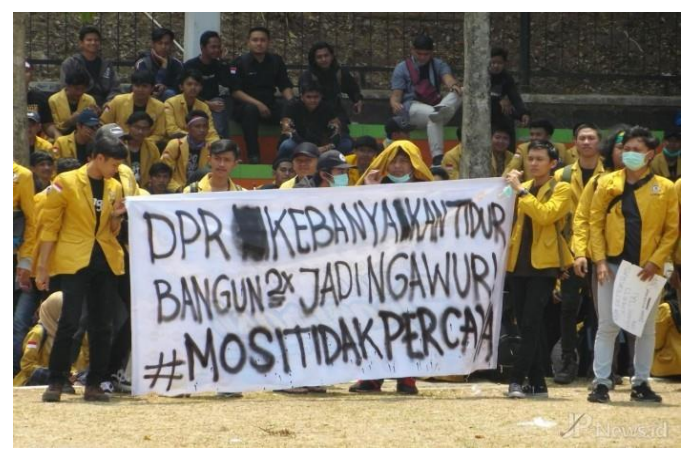

Gambar 7. Data 7 Sarkasme (tertanggal 18 Mei 2021)

Slogan ini mengandung makna bahwa DPR terlalu lama tidur dan tidak mengurusi tugas dan kewajibannya dan pada saat DPR itu bangun justru menjadi ngawur. Ngawur dalam slogan tersebut adalah membuat keputusan atau kebijakan yang tidak bisa diterima oleh masyarakat.

Pembuktian tersebut terdapat pada slogan yang telah diambil dan telah dianalisis, kutipan tersebut memiliki makna sarkasme atau termasuk kedalam gaya bahasa sarkasme, sebagaimana yang telah dijelaskan perihal gaya bahasa sarkasme yaitu gaya bahasa dalam ungkapannya menggunakan kata-kata kasar dengan maksud untuk mencemoohkan atau mengejek seseorang. Terbukti pada kalimat "DPR kebanyakan tidur" hal ini 
diungkapkan dengan kata-kata yang tidak pantas atau kasar dan dengan tujuan cemoohan, kutipan ini termasuk dalam gaya bahasa sarkasme karena pengungkapannya memiliki tujuan untuk mencemooh DPR. Kesimpulan kutipan slogan tersebut termasuk kedalam jenis gaya bahasa sarkasme karena mengandung makna yang mengejek secara langsung dengan tujuan melecehkan seseorang sebagaimana yang dijelaskan dalam makna gaya bahasa sarkasme dan dibuktikan pada kalimat "DPR kebanyakan tidur".

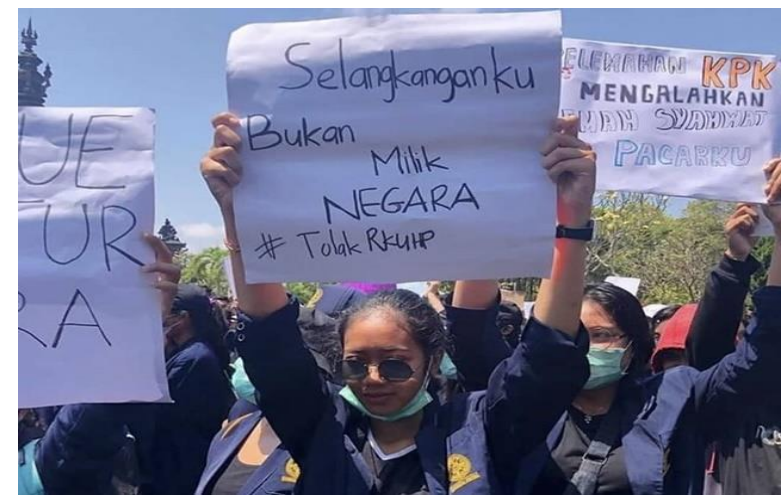

Gambar 8. Data 8 Sarkasme (tertanggal 18 Mei 2021)

Dalam slogan ini mengandung makna bahwa negara tidak berhak mengatur selangkangan, hal ini disebabkan karena regulasi yang dibuat oleh DPR terlalu mengatur hak-hak yang melibatkan privasi masyarakat.

Pembuktian tersebut terdapat pada slogan yang telah diambil dan telah dianalisis, kutipan tersebut memiliki makna sarkasme atau termasuk kedalam gaya bahasa sarkasme, sebagaimana yang telah dijelaskan perihal gaya bahasa sarkasme yaitu gaya bahasa dalam ungkapannya menggunakan kata-kata kasar dengan maksud untuk mencemoohkan atau mengejek seseorang. Hal ini terbukti pada kata "slangkanganku" kata ini adalah kata yang tidak baik untuk diungkapkan dalam komunikasi karena mengandung makna cemoohan terhadap sesuatu, maka slogan ini sesuai dengan makna gaya bahasa sarkasme.

Kesimpulan kutipan slogan tersebut termasuk kedalam jenis gaya bahasa sarkasme karena mengandung makna yang mengejek secara langsung dengan tujuan melecehkan seseorang sebagaimana yang dijelaskan dalam makna gaya bahasa sarkasme dan dibuktikan dengan kata "selangkanganku". Sejalan dengan makna Sarkasme menurut Mara \& Bahry, 2019 (dalam Keraf 2005:143) beliau menyatakan bahwa gaya bahasa sarkasme adalah merupakan sindiran yang lebih kasar dalam penggunaan kata atau frasenya dari gaya bahasa sinisme dan ironi. Sarkasme juga merupakan sebuah acuan yang menggunakan kepahitan celaan dalam sebuah pengungkapannya.

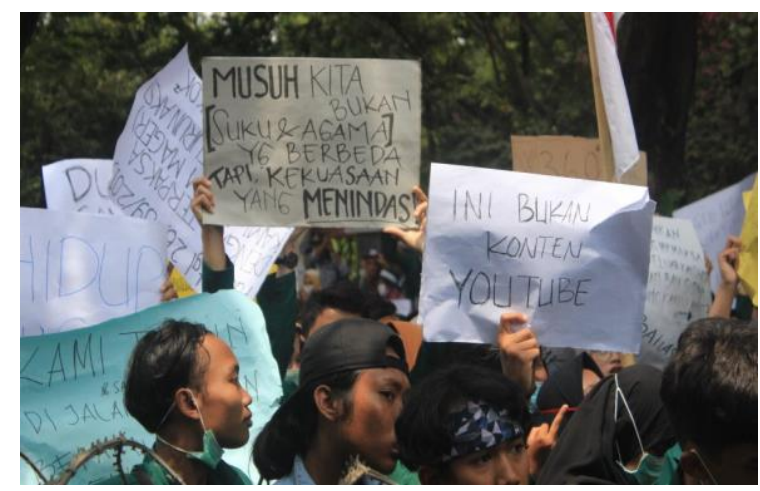

Gambar 9. Data 9 Satire (tertanggal 18 Mei 2021)

Makna yang terkandung dalam slogan ini mengungkapkan bahwa musuh yang dihadapi oleh negara Indonesia bukanlah suku dan agama, melainkan kekuasaan yang disalahgunakan oleh aparat pemerintah dengan menggunakan kekuasaannya untuk menindas hak-hak masyarakat.

Pembuktian tersebut terdapat pada slogan yang telah diambil dan telah dianalisis, kutipan tersebut memiliki makna satire atau termasuk kedalam gaya bahasa satire, sebagaimana yang telah dijelaskan yaitu gaya bahasa satire menggunakan atau menyatakan sebuah sindiran terhadap keadaan seseorang, menyindir keadaan seseorang dengan menggunakan sindiran yang kata-katanya halus namun menyakitkan. Hal ini dibuktikan 
dengan kalimat "kekuasaan yang menindas" makna kata tersebut mengandung sindiran terhadap keadaan seseorang yang tertindas. Maka dapat dikategorikan slogan ini termasuk dalam gaya bahasa satire.

Kesimpulannya adalah kutipan slogan tersebut termasuk kedalam jenis gaya bahasa satire karena mengandung makna yang menyatakan sebuah sindiran terhadap keadaan seseorang, sebagaimana yang dijelaskan dalam makna gaya bahasa satire dan dibuktikan dengan adanya kata kekuasaan yang menindas.

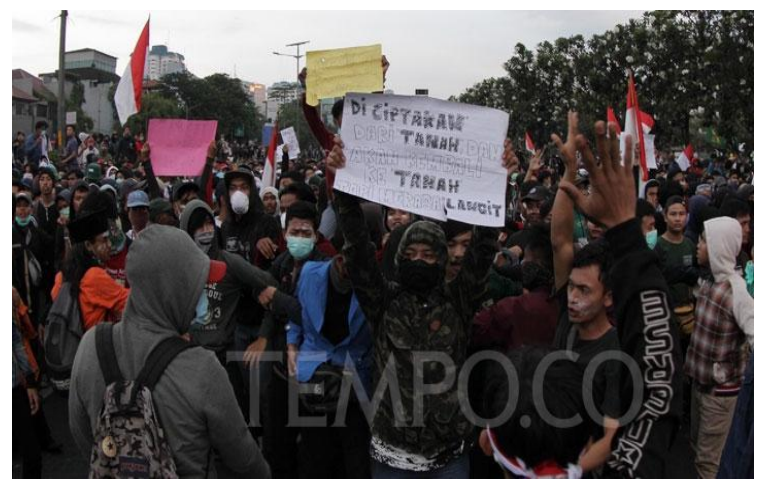

Gambar 10. Data 10 Satire (tertanggal 18 Mei 2021)

Makna yang terkandung pada slogan ini adalah diciptakan dari tanah dan akan kembali ke tanah tapi merasa langit. Slogan ini mempunyai makna bahwa sebagai manusia yang sama drajatnya di mata tuhan dan tercipta dari tanah yang akan kembali pula ke tanah, maka tidak sepantasnya kita merasa besar dan merasa sombong atau merasa menjadi seperti langit.

Pembuktian tersebut terdapat pada slogan yang telah diambil dan telah dianalisis, kutipan tersebut memiliki makna satire atau termasuk kedalam gaya bahasa satire, sebagaimana yang telah dijelaskan yaitu gaya bahasa satire menggunakan atau menyatakan sebuah sindiran terhadap keadaan seseorang, menyindir keadaan seseorang dengan menggunakan sindiran yang kata-katanya halus namun menyakitkan. Hal ini dibuktikan dengan kata "diciptakan dari tanah" dan kata "Kembali ke tanah" kata-kata tersebut menunjukan sebuah keadaan yang menyindir bahwa manusia tidak ada yang sempurna. Maka kutipan slogan ini sesuai dengan gaya bahasa satire.

Kesimpulannya adalah kutipan slogan tersebut termasuk kedalam jenis gaya bahasa satire karena mengandung makna yang menyatakan sebuah sindiran terhadap keadaan seseorang, sebagaimana yang dijelaskan dalam makna gaya bahasa satire dan dibuktikan dengan adanya kata diciptakan dari tanah dan kembali ke tanah. Hal ini sejalan dengan gaya bahasa satire yaitu majas yang cara pengungkapannya dengan menggunakan makna penguatan yang akan disampaikan, penerapannya seringkali dibentuk untuk ejekan atau hinaan ataupun untuk suatu bahan lelucon terhadap suatu hal. Gaya bahasa satire mengandung makna kritik terhadap kelemahan manusia yang memiliki tujuan utama agar diadakannya perbaikan atas ketidak sesuaian sesuatu secara etis maupun secara estetis. Keraf: 2005 (dalam Mara \& Bahry, 2019)

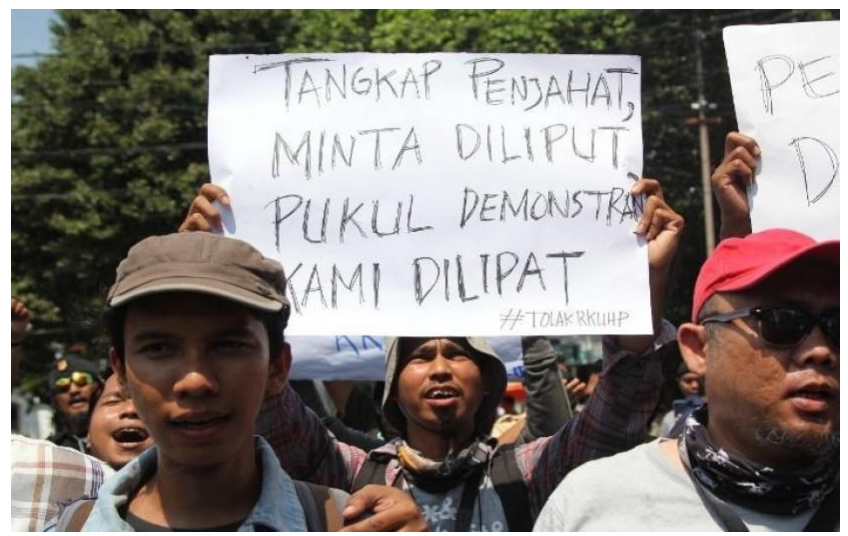

Gambar 11. Data 11 Inuendo (tertanggal 18 Mei 2021)

Makna yang terkandung dalam slogan ini adalah tertuju ke kepolisian yang berhasil menangkap penjahat dan ingin diliput oleh media, sedangkan ketika kepolisian memukul demonstran, justru demonstran tersebut yang dilipat atau disembunyikan. 
Pembuktian tersebut terdapat pada slogan yang telah diambil dan telah dianalisis, kutipan tersebut memiliki makna inuendo atau termasuk kedalam gaya bahasa inuendo, sebagaimana yang telah dijelaskan yaitu gaya bahasa inuendo mengecilkan suatu makna yang sebenarnya memiliki makna yang besar. Hal ini dibuktikan pada kata "tangkap penjahat minta diliput" dengan kata "pukul demonstran kami dilipat" makna tersebut mengungkapkan bahwa hal yang sebenarnya besar tetapi dibuat seakan akan biasa saja atau kecil. Maka dapat dikategorikan slogan ini dalam gaya bahasa inuendo.

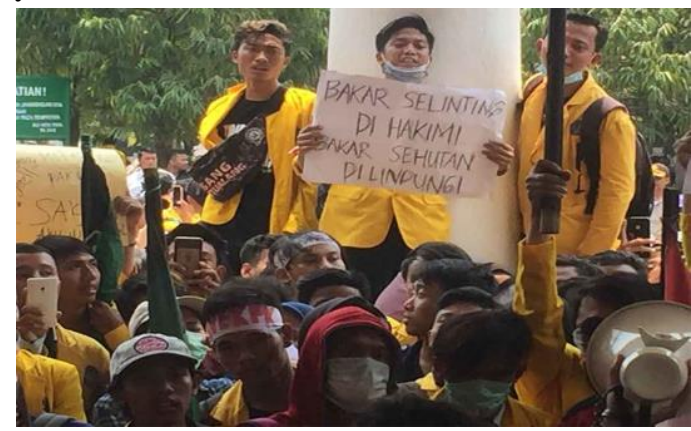

Gambar 12. Data 12 Inuendo (tertanggal 18 Mei 2021)

Makna yang terkandung dalam slogan ini adalah Ketika membakar rokok selintingan dihakimi, ketika ada yang membakar hutan justru dilindungi oleh aparat pemerintahan. Tergambarkan jelas regulasi yang dimiliki oleh negara ini begitu lemah jika dilihat dari kutipan slogan yang telah dibuat. Makna Hukum yang tertuangkan dalam slogan ini masih memilah dan memilih mana yang harus ditindak lanjuti lebih tegas.

Pembuktian tersebut terdapat pada slogan yang telah diambil dan telah dianalisis, kutipan tersebut memiliki makna inuendo atau termasuk kedalam gaya bahasa inuendo, sebagaimana yang telah dijelaskan yaitu gaya bahasa inuendo mengecilkan suatu makna yang sebenarnya memiliki makna yang besar. Hal ini terbukti pada kutipan "bakar selinting dihakimi" dengan kata "bakar sehutan dilindungi" makna yang terkandung sesuai dengan pengertian inuendo yang mengecilkan sesuatu makna yang sebenarnya memiliki makna lebih besar. Hal ini terbukti dengan adanya penjelasan tantang gaya bahasa sindiran inuendo adalah semacam gaya bahasa yang cara penggunaanya yaitu mengecilkan kenyataan yang sebenarnya (Jawa et al., 2016). Sejalan dengan pengertian inuendo yang merupakan bahasa sindiran yang mengecilkan kenyataan yang sebenarnya lebih besar (Nasrullah et al., 2021)

\section{SIMPULAN}

Berdasarkan hasil penelitian telah ditemukan makna figuratif atau gaya bahasa yang menjadi kajian dalam penelitian ini. Objek kajian dalam slogan unjuk rasa RKUHP di media online tahun 2019 yang meliputi gaya bahasa ironi, sinisme, sarkasme, satire, dan inuendo. Slogan yang dianalisis sebanyak 43 slogan unjuk rasa RKUHP di media online dengan rincian dari hasil pembahasan ini yang meliputi: gaya bahasa ironi ditemukan sebanyak 8 temuan, sinisme 11, gaya bahasa sarkasme 12, gaya bahasa satire 5, dan gaya bahasa inuendo sebanyak 7 temuan. Gaya bahasa sarkasme mendapatkan poin yang paling banyak dari gaya bahasa lainnya yang dianalisis. Maka dapat disimpulkan bahwa dalam aksi unjuk rasa RKUHP pada tahun 2019 slogan yang memonipoli aksi tersebut yaitu slogan yang mempunyai makna sarkasme yaitu menyindir dengan bahasa yang kasar dan melanggar teori kesantunan berbahasa. Harapan yang diinginkan dari hasil penelitian ini yaitu menjadikan penelitian selanjutnya menjadi semakin baik lagi dan bisa menjadi sumber referensi untuk penelitian selanjutnya khususnya dalam bidang pendidikan.

\section{UCAPAN TERIMA KASIH}

Ucapan terima kasih penulis sampaikan kepada Dosen Universitas Muhammadiyah PROF. DR. HAMKA khususnya Dosen di Program Studi Pendidikan Bahasa dan Sastra Indonesia karena telah memberikan dukungan sehingga penelitian ini dapat terselesaikan dengan baik.

\section{DAFTAR PUSTAKA}

Al-Houti, S. K., \& Aldaihani, S. M. (2020). Learners in a Tight Corner: An Investigation of Figurative Idiomatic Competence and Learner-related Factors. English Language Teaching, 13(4), 76. https://doi.org/10.5539/elt.v13n4p76

Azwar, S. (2014). METODE PENELITIAN (Udin (ed.); XV). PUSTAKA PELAJAR.

Creswell, J. W. (2017). RESEARCH DESIGN PENDEKATAN METODE KUALITATIF, KUANTITATIF, DAN CAMPURAN (A. F. dan R. K. Pancasari, H. El Rais, Priyati, \& Amaryllis (eds.); 4th ed.). PUSTAKA PELAJAR.

Fajaryati, N. (2012). Hubungan Kebiasaan Olahraga Dengan Dismenore Primer Remaja Putri Di Smp N 2 Mirit 
Kebumen. Jurnal Komunikasi Kesehatan, 3, 2-3. http://e-journal.akbidpurworejo.ac.id/index.php/jkk4/article/view/62

Fithrian, M., Syechalad, N., \& Nasir, M. (2015). ANALISIS PENGARUH AGGREGAT DEMAND DAN TINGKAT PENDIDIKAN TERHADAP KETIMPANGAN PENDAPATAN DI ACEH. Ilmu Ekonomi Pascasarjana Universitas Syiah Kuala, 3(3), 23-32.

Jawa, B., Akun, D. I., Dagelan, I., \& Pragmatik, K. S. (2016). 1 , 2 , 3.

Khair, U. (2018). Pembelajaran Bahasa Indonesia dan Sastra (BASASTRA) di SD dan MI. AR-RIAYAH : Jurnal Pendidikan Dasar, 2(1), 81. https://doi.org/10.29240/jpd.v2i1.261

Mara, R. S., \& Bahry, R. (2019). ANALISIS GAYA BAHASA SINDIRAN DALAM SYAIR DIDONG JALU ARITA MUDE DAN BIAK CACAK. 62 Jurnal Bahasa Dan Sastra, 13(1), 61-79.

Nasrullah, Susanti, D. I., \& Yunus, S. (2021). GAYA BAHASA PERTENTANGAN DALAM NOVEL BAHEBBAK PEMEBELAJARAN BAHASA INDONESIA. ALEGORI, 1(1), 121-127.

Simanjuntak, A. S. (2015). HAMBATAN KOMUNIKASI ANTARA APARAT POLISI DENGAN ALIANSI MAHASISWA PAPUA (AMP) SURABAYA Ade. Kanal, 4(1)(Goleman), 1-14.

Sugiyono. (2015). METODE PENELITIAN Kuantitatif, kualitiatif, dan R\&D (22nd ed.). ALFABETA, CV. Tohirin. (2016). METODE PENELITIAN KUALITATIF DALALM PENDIDIKAN DAN BIMBINGAN KONSELING (Tohirin (ed.); 1st ed., pp. 1-66). PT RajaGrafindo Persada.

Zaenuddin. (2020). Pengertian Slogan, Ciri, Fungsi, Macam-Macam, Contoh, Metode Menulis Slogan \& Arti Slogan Menurut Ahli. Artikelsiana.Com. https://artikelsiana.com/Pengertian-Slogan-Ciri-Fungsi-MacamContoh-Metode-Menulis-Slogan-Arti-Slogan-Menurut-Ahli/ 